\title{
MORPHOMETRIC CHARACTERIZATION OF THE SAND FRACTION IN A SAND GRAIN IMAGE CAPTURE SYSTEM ${ }^{1}$
}

\author{
Lucimar Arruda Viana ${ }^{2}$, Dario Cardoso de $\mathrm{Lima}^{3 *}$, Liovando Marciano da Costa ${ }^{4}$, Claudio Henrique de
} Carvalho Silva ${ }^{3}$, Weiner Gustavo Silva Costa ${ }^{2}$ and Yara Barbosa Franco ${ }^{5}$

\footnotetext{
${ }^{1}$ Received on 03.05.2013 accepted for publication on 08.09.2016.

${ }^{2}$ Universidade Federal de Viçosa, Programa de Pós-Graduação em Engenharia Civil, Viçosa, MG - Brasil. E-mail: $<$ lucimarvianna@hotmail.com> and <weinercosta@yahoo.com.br>.

${ }^{3}$ Universidade Federal de Viçosa, Centro de Ciências Exatas e Tecnológicas, Departamento de Engenharia Civil, Viçosa, MG - Brasil.E-mail: <declima@ufv.br> and <silvac@ufv.br>.

${ }^{4}$ Universidade Federal de Viçosa, Centro de Ciências Agrárias, Departamento de Solos, Viçosa, MG - Brasil. E-mail: $<$ liovando.costa@ufv.br>.

${ }^{5}$ Escola de Engenharia de São Carlos-USP, Programa de Pós-Graduação em Geotecnia, São Carlos, SP - Brasil. E-mail: <yarabarbb@yahoo.com.br>.

*Corresponding author.
}

\begin{abstract}
Morphology studies assume significant importance in analysis of phenomena of granular systems packaging, in particular with a view to the use of the technique of soil stabilization named particle size correction in forest roads. In this context, this study aimed to develop and operationalize a Sand Grain Image Capture System and, hereby, determine the morphological indices of the sand fractions of two sandy soils called João Pinheiro (JP) and Cachoeira da Prata (CP). Soil samples, air-dried, were sieved (2.0 mm nominal mesh size) for removal of gravels. The materials that passed through the sieve were subjected to dispersion, washing in $0.053 \mathrm{~mm}$ nominal mesh size sieve, removal of organic matter and iron oxides to obtain the clean sand fractions. Subsequently, each soil sample was sieved for separation into twelve classes, between the diameters of $0.149 \mathrm{~mm}$ and $1.190 \mathrm{~mm}$, using a Rotap shaker. Next, tests were carried out to characterize the morphometric attributes of the twelve classes of sand fractions of the soils studied. For validation of the performance of the Sand Grain Image Capture System, the results were compared to those obtained using a standard procedure for image analysis. The analysis of the results led to the following conclusions: (i) the sand fraction of the JP soil presented higher values for the morphometric indices roundness, elongation and compactness compared to sand fraction of the CP soil; and (ii) the Sand Grain Image Capture System worked properly, with practicality.
\end{abstract}

Keywords: Sandy soil; Sand morphology; Sand Grain Image Capture System.

\section{CARACTERIZAÇÃO MORFOMÉTRICA DA FRAÇÃO AREIA DE SOLOS UTILIZANDO UM SISTEMA DE CAPTURA DE IMAGENS DE GRÃOS DE AREIA}

\begin{abstract}
RESUMO - Estudos de morfologia assumem importância expressiva na análise de fenômenos de empacotamento em sistemas granulares, em especial com vistas ao emprego da técnica de estabilização de solos denominada correção granulométrica em estradas florestais. Neste contexto, o presente artigo teve como objetivo desenvolver e tornar operacional um Sistema para a Captura de Imagens de Grãos de Areia e, por meio deste, determinar os índices morfológicos da fração areia de dois solos arenosos denominados João Pinheiro (JP) e Cachoeira da Prata (CP). As amostras dos solos, após secagem ao ar, foram passadas na peneira de abertura nominal 2,0 $\mathrm{mm}$, para a retirada da fração pedregulho. Os materiais que passaram na peneira de 2,0 mm foram submetidos à dispersão, lavagem na peneira de abertura nominal $0,053 \mathrm{~mm}$, remoção de matéria orgânica e de óxidos de ferro, para obtenção das frações areia limpa dos solos. Posteriormente, cada amostra de solo foi submetida a peneiramento, para separação em doze classes, entre os diâmetros de 0,149 mm e 1,190
\end{abstract}


mm, utilizando-se um agitador tipo Rotap. Na sequencia, foram realizados ensaios de caracterização dos atributos morfométricos das doze classes das frações areias dos solos. Para fins de validação dos resultados obtidos com o Sistema de Captura de Imagem de Grãos de Areia, adotou-se como base o conjunto de resultados de parâmetros morfométricos determinados previamente com um sistema tradicional de análise de imagens. A análise dos resultados possibilitou concluir que: (i) a fração areia do solo JP apresentou valores superiores para os índices morfométricos arredondamento, compacidade e alongamento em comparação com a fração areia do solo CP; e (ii) o Sistema de Captura de Imagem de Grãos de Areia funcionou de forma adequada, com praticidade.

Palavras-chave: Solos arenosos; Morfologia de areias; Sistema de Captura de Imagens de Grãos de Areia.

\section{INTRODUCTION}

The network of Brazilian forest roads consists mainly of dirt roads, which present significant technical challenges in the design, construction and maintenance phases in order to remain in adequate conditions of transit throughout the year. In these roads, the soil is the building material par excellence, and the mechanical strength of the subgrade, in the case of design, and the prime coat, in situations of design and maintenance of roads, is of fundamental importance to ensure good performance along its useful life.

However, these roads do not always have soils with adequate mechanical strength for the construction or improvement of road pavement at economically viable transportation distances. This indicates the importance of using techniques for stabilization of local soils, especially the particle size correction that includes adding and or rearranging soil particles so as to produce alternative solutions for use in forest roads. This is the context of the present study.

The morphology comprises the study of particle shape. Generally, sedimentologists express this shape as a function of surface texture, sphericity and roundness, and analyses are often visual (ALSHIBLI; ALSALEH, 2004).

Under the geotechnical point of view and in granular soils, Das (2007) describes morphology as a consideration of similar importance to the particle size distribution, as it has significant influence on properties, such as the maximum and minimum void ratio, shear strength, permeability and compressibility. Moreover, the shape of the sand grains can be an important indicator of their origin; for example, sand particles located close to the origin, in general, are more angled, while those transported for long distances by wind and water tend to be rounded to subangular.

Revista Árvore, Viçosa-MG, v.40, n.5, p.893-899, 2016
Structurally, Pinto (2006) considers that the grain shape is important in geotechnical behavior of granular soils, as it influences the mechanical behavior of these materials, because it determines how particles fit together, mingle and slide on each other when requested by external forces. However, the author stresses that despite the importance of the grain shape, in Geotechnics, little attention has been given to this aspect in the classification of sand, mainly because of the lack of simple numerical indices to express the shape of grains.

The shape of grain particles is usually described by factors of shape, ranging between 0 and 1 , in which the unit is a sphere. These factors can be obtained, in many cases, in an image captured with the aid of a microscope, digital camera, or a combination of both, or even by other means.

In this context, the goal of this study was to develop and operationalize a system for capturing sand grain images, and hereby determine the morphological indices of the sand fraction of two sandy soils, and evaluate the performance of the system based on the morphometric parameters of these soils previously determined by Dalla Riva (2010), using a traditional system for analysis of sand grains images.

\section{MATERIALAND METHODS}

\subsection{Material}

\subsubsection{Soil}

In this research, it was used the clean sand fraction of two sandy soils studied by Dalla Riva (2010), with different morphometric parameters, namely: (i) Cachoeira da Prata (CP soil); and (ii) João Pinheiro (JP soil). A description of these soils and sampling sites is given below: 
CP soil: this soil has more angular particles; the sample was collected in an alluvial floodplain sediment, at the sand dredging site on the right side of MG 238, which connects the municipalities of Sete Lagoas, state of Minas Gerais, and Cachoeira da Prata, state of Minas Gerais, at the coordinates 19²9’59.06"S; $44^{\circ} 29^{\prime} 42.25^{\prime \prime} \mathrm{W}$; and

- JP soil: this soil has more rounded particles; the sample was taken in a Yellow Dystrophic Latosol, with sandy-loam texture, B horizon, in a cut slope located on the right side of MG 181, which connects the municipalities of João Pinheiro, state of Minas Gerais and Brasilândia de Minas, state of Minas Gerais, at the coordinates $17^{\circ} 25^{\prime} 48.65^{\prime \prime} \mathrm{S}$ and $46^{\circ} 04^{\prime} 37.27^{\prime \prime} \mathrm{W}$.

\subsection{Methods}

\subsubsection{Sample preparation}

Soil samples, air-dried, were sieved (2.0 mm nominal mesh size) for removal of gravels. The sieved material was pre-treated as follows: (i) sample dispersion - using a mechanical disperser for $16 \mathrm{~h}$, at $50 \mathrm{rpm}$, and by chemical dispersion, using $\mathrm{NaOH}$ at $0.5 \mathrm{~mol} / \mathrm{L}$ and deionized water; at the end of the process, the samples were washed on a sieve $(0.053 \mathrm{~mm}$ nominal mesh size $)$ to separate the sand fraction from silt and clay; (ii) removal of organic matter - using $\mathrm{NaClO} \mathrm{pH} 9.5$ in a water bath at $70^{\circ} \mathrm{C}$ for $6 \mathrm{~h}$ and, in sequence, washing the sample in running water; and (iii) removal of iron oxides - using dithionite-citrate solution in water bath for $1 \mathrm{~h}$, in three sequential extractions.

\subsubsection{Separation by sieving}

The separation of the different sand particle sizes was performed with certified sieves and a Rotap shaker, of controlled speed and rotary movements. Twelve classes of diameters between 0.149 and $1.190 \mathrm{~mm}$ were analyzed in the study.

\subsubsection{Morphometric characterization of the sand fraction}

The studies were conducted using a device called Sand Grain Image Capture System for morphometric analysis of sand and other objects that require magnification. The system combines the capabilities of an optical microscope and a digital camera. Figure 1 shows the main components of the Sand Grain Image Capture System.

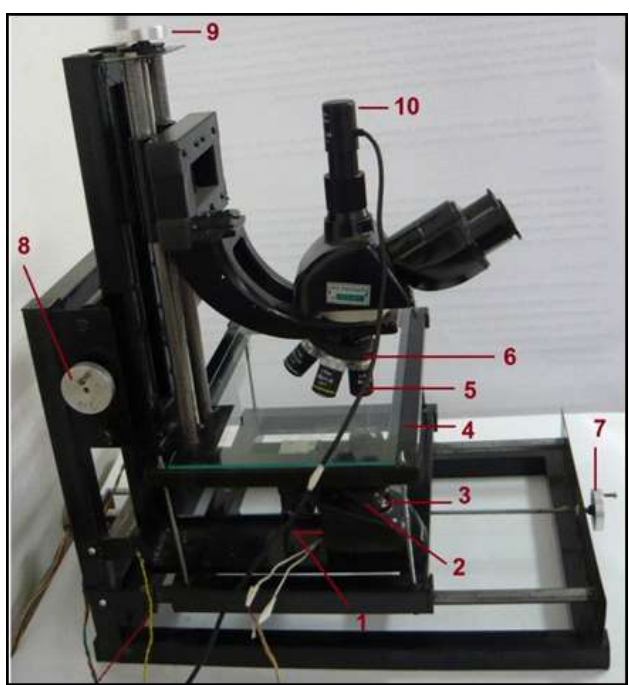

Figure 1 - Left side view of the Sand Grain Image Capture System (VIANA, 2013).

Figura 1 - Vista lateral esquerda do Sistema de Captura de Imagens de Grãos de Areia (VIANA, 2013).

Where:

- Light source: a lamp, with input voltage $110 \mathrm{~V} /$ $220 \mathrm{~V}$;

- Condenser: a set of two converging lenses that direct and regularly spread the light emitted by the light source;

- Diaphragm: controls the light intensity;

Mechanical table: function similar to the microscope stage. The upper part consists of tempered glass with 200 × $340 \mathrm{~mm}$;

- Objectives lens: produces magnifications of images of 5x, 10x, 40x, and 100x;

- Revolving turret: swivel for four objectives;

- Y gear: its rotation is responsible for horizontal movements of mechanical table, in the $\mathrm{Y}$ direction;

- X gear: its rotation allows horizontal movements of the optical part in the $\mathrm{X}$ direction;

$\mathrm{Z}$ gear: its rotation is responsible for vertical movements of the structure containing the Objectives. It is essential to focus; and

- Digital Camera MDCE 5A with a resolution of 1.3 Megapixels.

Revista Árvore, Viçosa-MG, v.40, n.5, p.893-899, 2016 
The equipment associated with a computer allows the view of the object on the glass plate of a mechanical table, positioning the camera properly and monitoring the number of photos, with the camera still or on the move. Proper positioning of the camera to take pictures of the sand grains or other object on the glass plate of the mechanical table depends on the correct position of the optical part and mechanical table. The optical part of the equipment can move in the $\mathrm{X}$ direction, whereas the mechanical table, in the $\mathrm{Y}$ direction. This movement is carried out automatically by means of motorized devices (controlled by engines) coupled in X and Y gears and controlled by specific hardware and software (included in the equipment). The use of software allows to adjusting the frequency of the drive and the speed of engines.

The clean sand soil fractions CP and JP were photographed using a MDCE 5A digital camera with 1.3 Megapixels resolution ( $1280 \times 1024 \mathrm{dpi})$ coupled to the optical microscope of the Sand Grain Image Capture System.

For image processing, it was used the Adobe ${ }^{\circledR}$ Photoshop ${ }^{\circledR}$ CS software, to convert all image pixel values to black and white values. It was then removed the particles which had contact with other particles and which had been cut, being located at the image edges. The images were calibrated with the aid of a micrometer bar and the ImageJ software.

With processed and calibrated images, it was used the software QUANTIPORO (FERNANDES FILHO; VIANA, 2001) to generate the following morphometric attributes: area, perimeter, roundness, major axis and minor axis. The value of the roundness index ranges from 0 to 1 , and the closer the value to 1 , the rounder the object is. Therefore, if the value is 1 , the object is a perfect circle.

The attributes elongation and compactness were calculated with the aid of spreadsheet processor in Microsoft Office Excel 2007. The elongation index ranges between 0 and 1 , the farther from 1 is the value, the more elongated the object is. This parameter is estimated by Equation (1).

$$
A l=\frac{M e}{M a}
$$

Where:

$A l=$ elongation $\left[\mathrm{LL}^{-1}\right] ; M e=$ length of the minor axis [L]; and $M a=$ length of the major axis [L].

Revista Árvore, Viçosa-MG, v.40, n.5, p.893-899, 2016
Regarding the compactness index, the result lies between 0 and 1 , and the farther from 1 the value is, the less circular the object is. This parameter was obtained by Equation (2).

$$
C o=\frac{\sqrt{\frac{4 A}{\pi}}}{M a} .
$$

Where:

$\mathrm{Co}=$ compactness $\left[\mathrm{LL}^{-1}\right] ; \mathrm{A}=$ area $\left[\mathrm{L}^{2}\right]$; and $\mathrm{Ma}$ $=$ major axis $[\mathrm{L}]$.

The performance evaluation of the Sand Grain Image Capture System was carried out comparing the morphometric attributes obtained with this system with those determined for these soils by Dalla Riva (2010), using a traditional system of image analysis based on a digital camera Nikon Coolpix 4500 with CCD of 4.0 Megapixels coupled to an Olympus microscope $\mathrm{CH} 30$.

\section{RESULTS}

\subsection{Morphometric characterization of the clean sand fraction}

In this study, twelve classes were considered for each of the soils analyzed. To obtain the morphometric indices roundness, elongation and compactness, at least, 200 particles in each class were used. Table 1 presents the different classes considered, where the first class number represents the sieve where all the particles passed through and the second is the sieve where the particles were retained.

Figures 2A and 2B illustrate, respectively, the clean sand fractions of CP and JP soils, with both images obtained by the Sand Grain Image Capture System.

Figure 3 shows, respectively, the results of morphometric indices roundness, compactness and elongation for soils studied.

\subsection{Validation of the Sand Grain Image Capture System}

Figure 4 shows the comparisons between the results of morphometric indices roundness, compactness and elongation, depending on the size classes obtained in this study and those determined by Dalla Riva (2010) based on a traditional system for image analysis. 
Table1 - Classes used for the determination of the morphometric indices roundness, compactness and elongation of soils $\mathrm{CP}$ and JP.

Tabela 1 - Classes utilizadas para a determinação dos índices morfométricos arredondamento, compacidade e alongamento dos solos CP e JP.

\begin{tabular}{cccc}
\hline Representation & Class $(\mathrm{mm})$ & Representation & Class (mm) \\
\hline 1 & $0.177-0.149$ & 7 & $0.500-0.420$ \\
2 & $0.210-0.177$ & 8 & $0.590-0.500$ \\
3 & $0.250-0.210$ & 9 & $0.710-0.590$ \\
4 & $0.297-0.250$ & 10 & $0.840-0.710$ \\
5 & $0.350-0.297$ & 11 & $1.000-0.840$ \\
6 & $0.420-0.350$ & 12 & $1.190-1.000$ \\
\hline
\end{tabular}

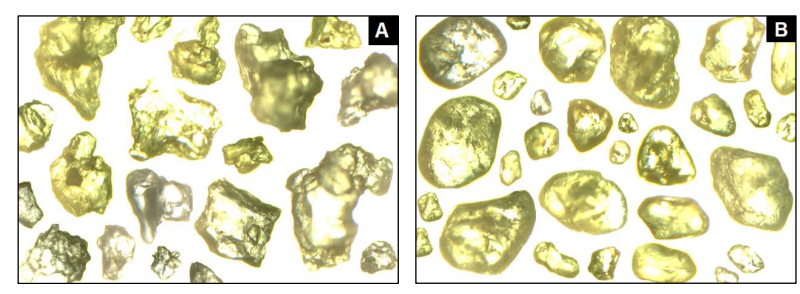

Figure 2 - Images of the clean sand fractions of soils CP (A) and JP (B) obtained using the Sand Grain Image Capture System (VIANA, 2013).

Figura 2 - Imagens das frações areia limpa dos solos $C P$ (A) eJP (B) obtidas através do Sistema de Captura de Imagens de Grãos de Areia (VIANA, 2013).

\section{DISCUSSIONS}

In Figure 3, it can be seen the morphometric index roundness, which expresses the degree of sharpness or curvature of the corners and edges of a particle. As expected from the visual observation of the images of sand grains in Figure 2, the clean sand fraction of the JP soil has a roundness index in the range 0.810.84 , therefore, greater than that of the $\mathrm{CP}$ soil, which is between 0.70 and 0.73 , evidencing the relatively low roughness of the first.

Analyzing the data in Figure 3, it is also verified the compactness index, which reflects the circularity of the object. The clean sand fraction of the JP soil was between 0.85 and 0.91 , close to the circular shape. In turn, in the clean sand fraction of the CP soil, compactness ranged from 0.81 to 0.86 .

The elongation index indicates the similarity between the major axis and the minor axis, and the lower its value, the flatter the particle is. As shown in Figure 3, the elongation index of the clean sand fraction of the CP soil varied from 0.81 to 0.85 , and the clean sand fraction of the JP soil was between 0.85 and 0.89 .
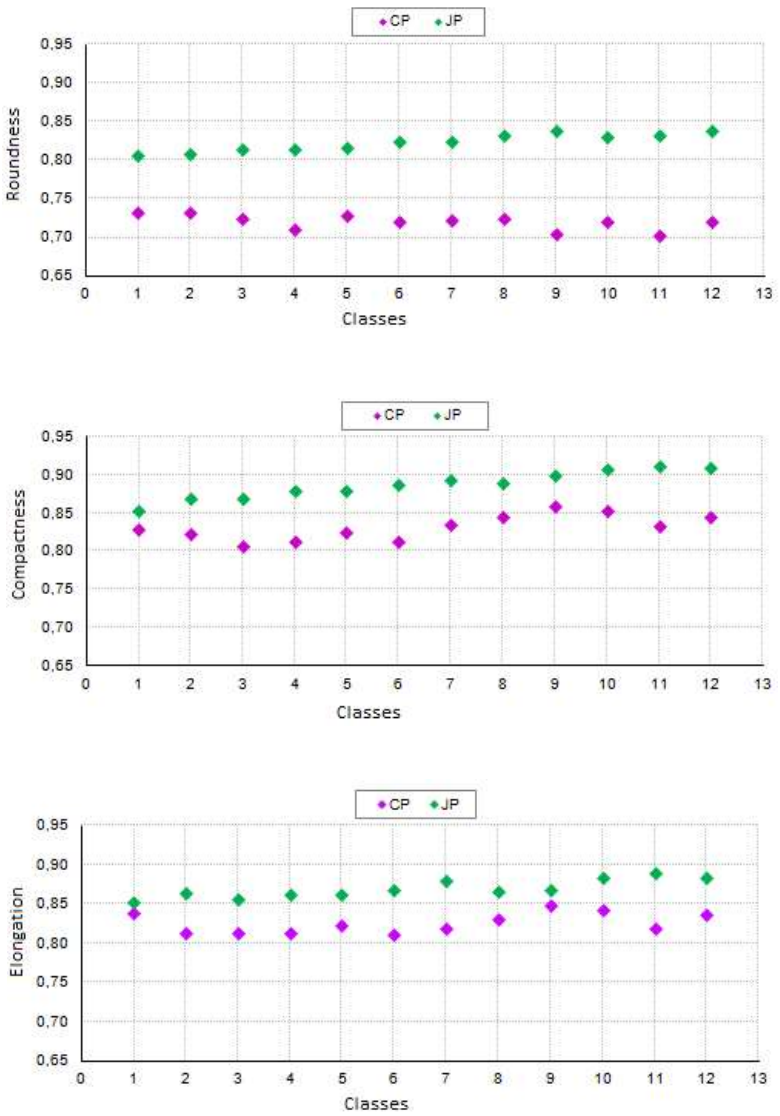

Figure 3 - Morphometric indices roundness, compactness and elongation of CP and JP soils based on size classes.

Figura 3-Índices morfométricos arredondamento, compacidade e alongamento dos solos CP eJP em função das classes de tamanho.

Based on the data in Figure 4, comparatively, it was observed that there was a slight variation between the results of morphometric indices roundness, compactness and elongation obtained by Dalla Riva (2010) and those determined in this

Revista Árvore, Viçosa-MG, v.40, n.5, p.893-899, 2016 

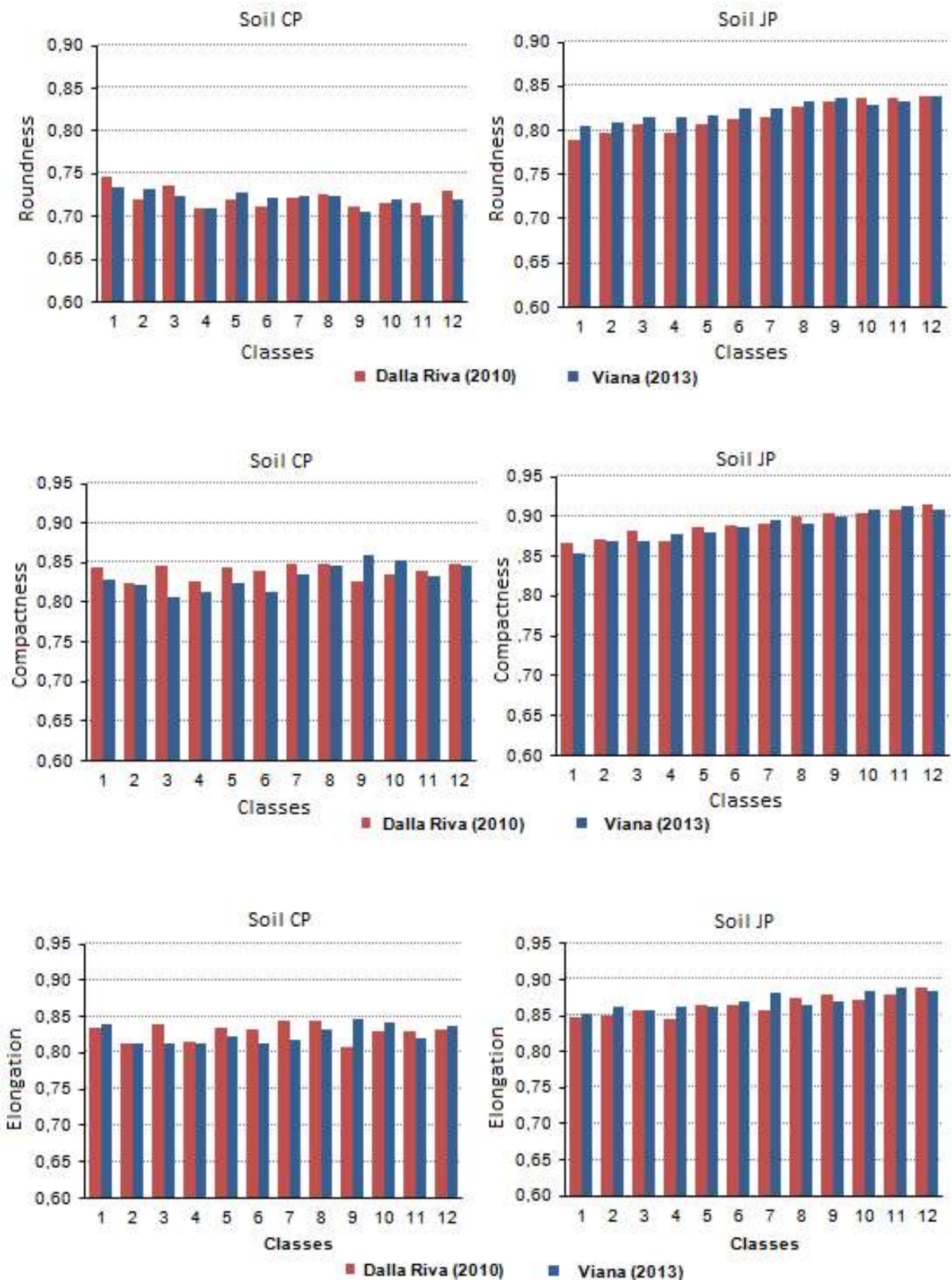

Figure 4-Comparison among the morphometric indices roundness, compactness and elongation of CP and JP soils obtained in this paper and by Dalla Riva (2010).

Figura 4 - Comparação entre os índices morfométricos arredondamento, compacidade e alongamento dos solos CP eJP obtidos neste trabalho e por Dalla Riva (2010).

study. This inconsistency can be considered as common, given the diversity of shapes and particle characteristics that constitute the $\mathrm{CP}$ and JP soils. Moreover, the difference in resolution of the images obtained in the sands by Dalla Riva (2010), based

Revista Árvore, Viçosa-MG, v.40, n.5, p.893-899, 2016 on resolution of 4.0 Megapixels, and in this study, using resolution of 1.3 Megapixels, probably also contributed to the small variation observed in the results, considering that high resolution images produce greater details of the edges of the particle, 
increasing the value of the perimeter related to the lower resolution images.

In this research, it was observed that the interference of the resolution was more evident in rough particles, with size smaller than $0.125 \mathrm{~mm}$. Because it were used classes above this size, this influence was relatively small. It should be stressed that, if higher resolution images (e.g. above 1.3 megapixels) are required, it is possible to replace the microscope camera in the Sand Grain Image Capture System developed in this work.

Due to the small difference between the results of morphometric indices roundness, elongation and compactness obtained by Dalla Riva (2010) and those determined herein, shown in Figure 4, it is claimed that the Sand Grain Image Capture System worked adequately, allowing the morphometric characterization of the sand clean fraction of CP and JP soils with considerable practicality. As limitations of the image capture system developed, it is emphasized that images obtained of grain sizes smaller than $0.125 \mathrm{~mm}$ were blurred even by changing the microscope objective and making the necessary adjustments; on the other hand, the particles with sizes larger than $1.119 \mathrm{~mm}$ resulted in images larger than the screen, remaining only part of the image in the system.

\section{CONCLUSIONS}

Based on the results obtained in this study, it can be concluded that: (i) the sand fraction of the JP soil has higher values for morphometric indices roundness, elongation and compactness compared with the sand fraction of the CP soil; and (ii) the equipment Sand Grain Image Capture System worked properly, with practicality.

\section{ACKNOWLEDGEMENTS}

The authors express their gratitude to CAPES, for the scholarship to the first author and CNPq and FAPEMIG for scientific initiation scholarships and financial support needed for this research, respectively, through the grants CNPq 304171/2010-7 and TEC PPM 00081-10.

\section{REFERENCES}

ASSOCIAÇÃO BRASILEIRA DE NORMAS

TÉCNICAS - ABNT. NBR 6502: rochas e solos - terminologia. Rio de Janeiro: 1995. $18 \mathrm{p}$.

ALSHIBLI, K.A.; ALSALEH, M.I. Characterizing surface roughness and shape of sands using digital microscopy. Journal of Computing in Civil Engineering, v. 18, p.36-45, 2004.

DALlA RIVA, R.D. Efeito das Propriedades Físicas dos grãos e Agente de

Cimentação na estruturação da Fração Areia de Solos Arenosos. 2010. 157f. Tese (Doutorado em Engenharia Civil) - Universidade Federal de Viçosa, Viçosa, MG, 2010.

DAS, B. M. Fundamentos de Engenharia Geotécnica. São Paulo: Thomson Learning, 2007.560p.

FERNANDES FILHO, E.I.; VIANA, J.H.M. QUANTIPORO: um novo programa para tratamento e quantificação de imagens digitais para aplicações em ciência do solo. In: Congresso Brasileiro de Ciência do Solo, 28., 2001, Londrina. Resumos... Londrina: Sociedade Brasileira de Ciência do Solo, 2001. p.224.

PINTO, C.S. Curso básico de mecânica dos solos em 16 aulas. $3^{a}$. ed. São Paulo: Oficina de Textos, 2006. 367p.

VIANA, L.A. Efeitos da cimentação e da morfologia na condutividade hidráulica e na resistência mecânica de empacotamentos binários. 2013. 109f. Dissertação (Mestrado em Engenharia Civil) Universidade Federal de Viçosa, Viçosa, MG, 2013. 